\title{
SDC1 wt Allele
}

National Cancer Institute

\section{Source}

National Cancer Institute. SDC1 wt Allele. NCI Thesaurus. Code C96913.

Human SDC1 wild-type allele is located in the vicinity of 2 p24.1 and is approximately 24 $\mathrm{kb}$ in length. This allele, which encodes syndecan-1 protein, plays a role in the modulation of signal transduction, cytoskeletal remodeling and cell adhesion. 